\title{
Two new organotin(IV)-phosphoryl complexes: crystal structure and Hirshfeld surface analysis
}

\author{
Mehrdad Pourayoubi ${ }^{1} \cdot$ Anahid Saneei $^{1} \cdot$ Michal Dušek $^{2} \cdot$ Soobiyeh Alemi Rostami $^{1}$. \\ Aurelien Crochet ${ }^{3} \cdot$ Monika Kučeraková $^{2}$
}

\begin{abstract}
Hirshfeld surfaces and two-dimensional fingerprint plots are used to visualize and analyse intermolecular interactions in two new organotin(IV)-phosphoryl complexes: $\left[\mathrm{Sn}\left(\mathrm{CH}_{3}\right)_{2}\left[\mathrm{OP}(\mathrm{O})\left(\mathrm{OCH}_{3}\right)_{2}\right]_{2}\right]_{\mathrm{n}}$ (I) and $\left\{\left[\left(4-\mathrm{CH}_{3}\right)\right.\right.$ $\left.\left.\mathrm{C}_{6} \mathrm{H}_{4} \mathrm{NH}\right]\left[\mathrm{C}_{5} \mathrm{H}_{9}\left(4-\mathrm{CH}_{3}\right) \mathrm{N}\right]_{2} \mathrm{P}(\mathrm{O})\right\} \mathrm{Sn}\left(\mathrm{CH}_{3}\right)_{2} \mathrm{Cl}_{2}$ (II). In (I), the asymmetric unit is composed of the $\mathrm{Sn}\left(\mathrm{CH}_{3}\right)_{2} \mathrm{OP}(\mathrm{O})$ $\left.\left(\mathrm{OCH}_{3}\right)_{2}\right]_{2}$ segment bonded to the neighbouring segment through $\mathrm{Sn}-\mathrm{O}$ bonds thus constructing a coordination polymer. The tin centre has an $\mathrm{Sn}[\mathrm{C}]_{2}[\mathrm{O}]_{4}$ environment with the axial positions occupied by methyl groups and with the oxygen atoms of $\mathrm{Sn}-\mathrm{O}$ bonds located at the equatorial plane, while the oxygen atoms of $\mathrm{OCH}_{3}$ groups do not take part in the coordination interaction. In (II), the asymmetric unit contains one complete molecule and the tin centre has an $\mathrm{Sn}[\mathrm{C}]_{2}[\mathrm{Cl}]_{2} \mathrm{O}$ trigonal bipyramid coordination environment, where the phosphoric triamide ligand and one of the chlorine atoms are placed in axial positions. Hirshfeld surface analysis on the asymmetric unit of (I) shows a contribution of $5.9 \%$ of total interactions in crystal for Sn...O contacts related to involving of four-coordinated Sn site of asymmetric unit with two oxygen atoms of two neighbouring phosphates in the coordination polymer. The Sn centre
\end{abstract}

Electronic supplementary material is available

Mehrdad Pourayoubi

pourayoubi@um.ac.ir

1 Department of Chemistry, Faculty of Sciences, Ferdowsi University of Mashhad, Mashhad, Iran

2 Institute of Physics ASCR, v.v.i., Na Slovance 2, 18221 Prague 8, Czech Republic

3 Fribourg Centre for Nanomaterial's, FriMat, University of Fribourg, Chemin duMusee 3, 1700 Fribourg, Switzerland in the asymmetric unit of (II) receives a second interaction from chlorine atom that, however, has negligible contribution portion in the total interactions (evaluated by fingerprint plot) in the crystal. On the other hand, this chlorine affects the geometry at the $\mathrm{Sn}$ atom and causes the open $\mathrm{C}-\mathrm{Sn}-\mathrm{C}$ bond angle (of $140.18(24)^{\circ}$ ). For both structures, the contribution of $\mathrm{H}$...H contacts to the total interaction is decisive, being $59.1 \%$ for (I) and $73.9 \%$ for (II); so that the one distinct spike observed in each of the fingerprint plots is related to H...H contacts. The O...H (34.1\%) in (I) and the $\mathrm{H} \ldots \mathrm{Cl}(20.2 \%)$ in (II) are the characteristic intermolecular contacts in the corresponding structures, monitoring as two pairs of $\mathrm{H}$-bond spikes for $\mathrm{O}$...H and two sharp spikes for H...Cl. Furthermore, the structure (I) does not show the C...H interaction, whereas (II) including unsaturated carbon atoms manifests such interaction $(5.7 \%)$ as two very short spikes.

Keywords Organotin(IV)-phosphoryl complex · Hirshfeld surface $\cdot$ Crystal structure

\section{Introduction}

Tin complexes are of great interest because of their unique properties in medicine, industrial applications and biological systems [1-4]. Among which the tin-phosphoryl complexes have received considerable attention due to the diverse structural features known for phosphoryl-donor ligands [5] and various applications such as anti-bacterial [6], anti-HIV [7] and anti-cancer [8] activities and also agricultural uses [9] and enzyme inhibitory [10] for phosphoryl compounds.

Up to now, different families of phosphoryl compounds, with different coordination environment at the $\mathrm{P}$ atom 
have been used in preparation of tin complexes, for example compounds with $[\mathrm{N}]_{3} \mathrm{P}(\mathrm{O})[11-13], \mathrm{C}(\mathrm{O}) \mathrm{NHP}(\mathrm{O})[\mathrm{N}]_{2}$ $[11,14-16],[\mathrm{C}][\mathrm{N}]_{2} \mathrm{P}(\mathrm{O})[17],[\mathrm{O}]_{2} \mathrm{P}(\mathrm{O})[\mathrm{OH}][18,19]$ and $[\mathrm{O}]_{3} \mathrm{P}(\mathrm{O})[20,21]$ segments. Moreover, different coordination environments [22, 23] and coordination numbers [24, $25]$ at the Sn atom and also coordination modes (monomer [20], dimer [18, 26], polymer [27-29] and so on [30, $31]$ ) and crystal packing diagrams have been found among through the tin-phosphoryl complexes structures deposited in the Cambridge Structural Database (CSD, version 5.35, February 2014 update) [32].

In this work, we report two complexes of organotin(IV): a novel one-dimensional coordination polymer with the formula $\left[\mathrm{Sn}\left(\mathrm{CH}_{3}\right)_{2}\left[\mathrm{OP}(\mathrm{O})\left(\mathrm{OCH}_{3}\right)_{2}\right]_{2}\right]_{\mathrm{n}}$ (I) (Scheme 1) and a novel five-coordinated complex, $\left\{\left[\left(4-\mathrm{CH}_{3}\right) \mathrm{C}_{6} \mathrm{H}_{4} \mathrm{NH}\right]\right.$ $\left.\left[\mathrm{C}_{5} \mathrm{H}_{9}\left(4-\mathrm{CH}_{3}\right) \mathrm{N}\right]_{2} \mathrm{P}(\mathrm{O})\right\} \mathrm{Sn}\left(\mathrm{CH}_{3}\right)_{2} \mathrm{Cl}_{2}$ (II) (Scheme 2). The close intermolecular interactions are studied using the program Crystal Explorer 3.1 with the Hirshfeld surface analysis. It has been found that, through a search on the CSD, the coordination polymer (I) is the first example of a onedimensional organotin(IV)-phosphate coordination polymer with the $\mathrm{Sn}[\mathrm{C}]_{2}[\mathrm{O}]_{4}$ coordination environment. Also, complex (II) is the second crystal structure of a pentacoordinated Sn complex of the type $\left([R N H]\left[R^{\prime} \mathrm{R}^{\prime \prime} \mathrm{N}\right]_{2} \mathrm{P}(\mathrm{O})\right.$ ) $\mathrm{SnX}_{2} \mathrm{Me}_{2}, \mathrm{X}=$ halide. The one already published structure of this type is: $\left(\left[\left(\mathrm{CH}_{3}\right)_{3} \mathrm{CNH}\right]\left[\left(\mathrm{C}_{6} \mathrm{H}_{5} \mathrm{CH}_{2}\right)\left(\mathrm{CH}_{3}\right) \mathrm{N}\right]_{2} \mathrm{P}(\mathrm{O})\right)$ $\mathrm{SnCl}_{2} \mathrm{Me}_{2}$ [33].

\section{Experimental}

\section{Materials and measurement}

Dimethyltin(IV) dichloride, diethyl amine, 4-methyl piperidine, $p$-toluidine, phosphoryl chloride, phosphorus pentoxide and methanol were commercially available. Chloroform was dried with $\mathrm{P}_{2} \mathrm{O}_{5}$ and distiled prior to use. The synthesis of the ligand $\left[\left(\mathrm{C}_{2} \mathrm{H}_{5}\right)_{2} \mathrm{~N}\right]_{3} \mathrm{P}(\mathrm{O})$ was performed by a literature procedure [34]. IR spectra were recorded on a Buck 500 scientific spectrometer using a $\mathrm{KBr}$ disk. For (I), data collection using Mo- $K_{\alpha}$ radiation $(\lambda=0.71073 \AA)$ was performed with a STOE IPDS II diffractometer with graphite monochromator and was solved and refined using fullmatrix least squares on $F^{2}$ with the SHELX-97 [35]. Data for (II) were obtained at $120 \mathrm{~K}$ on a single crystal diffractometer Gemini with mirrors-collimated $\mathrm{Cu}-K_{\alpha}$ radiation $(\lambda=1.5418 \AA)$, solved by the charge flipping algorithm of Superflip [36] and refined by Jana2006 [37].

Synthesis of $\left[\mathrm{Sn}\left(\mathrm{CH}_{3}\right)_{2}\left[\mathrm{OP}(\mathrm{O})\left(\mathrm{OCH}_{3}\right)_{2}\right]_{2}\right]_{\mathrm{n}}$ (I). The compound (I) was obtained fortuitously from a reaction between $\left[\left(\mathrm{C}_{2} \mathrm{H}_{5}\right)_{2} \mathrm{~N}\right]_{3} \mathrm{P}(\mathrm{O})(1.15 \mathrm{mmol})$ and $\mathrm{SnMe}_{2} \mathrm{Cl}_{2}$ $(0.56 \mathrm{mmol})$ in $\mathrm{CH}_{3} \mathrm{OH}(20 \mathrm{ml})$ under reflux condition for $48 \mathrm{~h}$. Colourless single crystals were obtained by slow

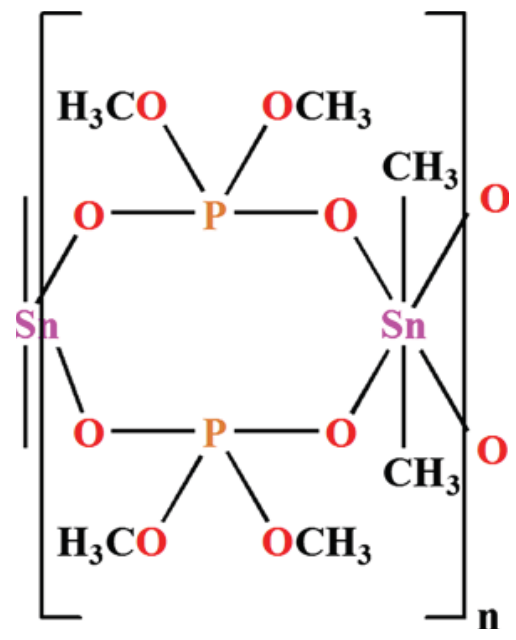

Scheme 1 Chemical structure of coordination polymer (I)

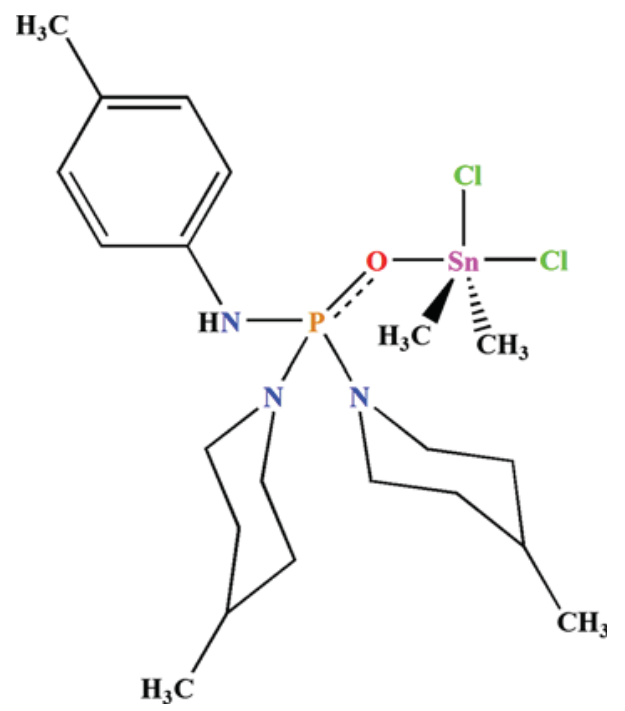

Scheme 2 Chemical structure of complex (II)

evaporation at room temperature. IR $\left(\mathrm{KBr}, \nu, \mathrm{cm}^{-1}\right)$ : 792, 841, 1046, 1100, 1186, 1361, 1740, 2961.

Synthesis of $\left[4-\mathrm{CH}_{3}-\mathrm{C}_{6} \mathrm{H}_{4} \mathrm{NH}\right]\left[\mathrm{C}_{5} \mathrm{H}_{9}\left(4-\mathrm{CH}_{3}\right) \mathrm{N}\right]_{2} \mathrm{P}(\mathrm{O})$. For synthesis of ligand, the $\left[4-\mathrm{CH}_{3}-\mathrm{C}_{6} \mathrm{H}_{4} \mathrm{NH}\right] \mathrm{P}(\mathrm{O}) \mathrm{Cl}_{2}$ reagent was prepared from a reaction between $\mathrm{P}(\mathrm{O}) \mathrm{Cl}_{3}(32.15 \mathrm{mmol})$ and $p$-toluidine $(64.30 \mathrm{mmol})$ in dry $\mathrm{CH}_{3} \mathrm{CN}(25 \mathrm{ml})$ at $0{ }^{\circ} \mathrm{C}$ under stirring for $4 \mathrm{~h}$. The formed solid was removed by filtration. The reagent was obtained from the filtrate solution after removing the solvent in vacuo. In the next step, to a solution of $\left[4-\mathrm{CH}_{3}-\mathrm{C}_{6} \mathrm{H}_{4} \mathrm{NH}\right] \mathrm{P}(\mathrm{O}) \mathrm{Cl}_{2}(4.54 \mathrm{mmol})$ in dry $\mathrm{CHCl}_{3}$ $(15 \mathrm{ml})$, a solution of 4-methyl piperidine $(18.16 \mathrm{mmol})$ in the same solvent $(15 \mathrm{ml})$ was added at $0{ }^{\circ} \mathrm{C}$ under stirring. After $4 \mathrm{~h}$, the solvent was evaporated in vacuo and the solid (including the salt $\left[\left(\mathrm{C}_{5} \mathrm{H}_{9}\left(4-\mathrm{CH}_{3}\right) \mathrm{NH}_{2}^{+}\right] \mathrm{Cl}^{-}\right)$was washed with distiled water to obtain the pure ligand. IR $(\mathrm{KBr}, \nu$, 
Table 1 Crystallographic data for complexes (I) and (II)

\begin{tabular}{|c|c|c|}
\hline Parameter & (I) & (II) \\
\hline Empirical formula & $\mathrm{C}_{6} \mathrm{H}_{18} \mathrm{O}_{8} \mathrm{P}_{2} \mathrm{Sn}$ & $\mathrm{C}_{21} \mathrm{H}_{38} \mathrm{Cl}_{2} \mathrm{~N}_{3} \mathrm{OPSn}$ \\
\hline Formula weight & 398.83 & 596.1 \\
\hline Temperature (K) & $200(2)$ & $119.9(5)$ \\
\hline Wavelength $(\AA)$ & 0.71073 & 1.54184 \\
\hline Crystal system & Monoclinic & Triclinic \\
\hline Space group & $P 2_{1} / c$ & $P-1$ \\
\hline \multicolumn{3}{|l|}{ Unit cell dimensions } \\
\hline$a(\AA)$ & $10.9403(10)$ & $9.0431(2)$ \\
\hline$b(\AA)$ & $12.7296(11)$ & $10.9879(2)$ \\
\hline$c(\AA)$ & $10.5843(9)$ & $14.5773(3)$ \\
\hline$\alpha\left(^{\circ}\right)$ & 90 & 75.9464(19) \\
\hline$\beta\left(^{\circ}\right)$ & $103.353(7)$ & $80.0934(19)$ \\
\hline$\gamma\left({ }^{\circ}\right)$ & 90 & $70.395(2)$ \\
\hline Volume $\left(\AA^{3}\right)$ & $1434.2(2)$ & $1317.14(5)$ \\
\hline$Z$ & 4 & 2 \\
\hline Density (calculated) $\left(\mathrm{Mg} / \mathrm{m}^{3}\right)$ & 1.847 & 1.4346 \\
\hline Absorption coefficient $\left(\mathrm{mm}^{-1}\right)$ & 2.028 & 10.279 \\
\hline$F(000)$ & 792 & 584 \\
\hline Theta range for data collection $\left(^{\circ}\right)$ & 1.91 to 25.61 & 3.14 to 67.03 \\
\hline Index ranges & $-13 \leq h \leq 13,-15 \leq k \leq 15,-12 \leq l \leq 12$ & $-10 \leq h \leq 10,-13 \leq k \leq 13,-17 \leq l \leq 17$ \\
\hline Reflections collected & 17678 & 32515 \\
\hline Independent reflections & $2516[R($ int $)=0.0426]$ & $4680\left[R\left({ }_{\text {int }}\right)=0.043\right]$ \\
\hline Refinement method & Full-matrix least-squares on $F^{2}$ & Full-matrix least-squares on $F^{2}$ \\
\hline Data/restraints/parameters & $2516 / 0 / 160$ & $4680 / 6 / 283$ \\
\hline Goodness-of-fit on $F^{2}$ & 0.918 & 1.14 \\
\hline Final $R$ indices & $R_{1}=0.0227, w R_{2}=0.0499$ & $R_{1}=0.0221, w R_{2}=0.0595$ \\
\hline$R$ indices (all data) & $R_{1}=0.0389, w R_{2}=0.0534$ & $R_{1}=0.254, w R_{2}=0.0623$ \\
\hline Largest diff. peak and hole $\left(\mathrm{e} . \AA^{-3}\right)$ & 0.387 and -0.542 & 0.25 and -0.30 \\
\hline
\end{tabular}

$\left.\mathrm{cm}^{-1}\right):$ 682, 816, 946, 1061, 1195, 1243, 1286, 1344, 1382, 1449, 1516, 1622, 2844, 2916, 3029, 3070, 3146.

Synthesis of $\left\{\left[4-\mathrm{CH}_{3} \mathrm{C}_{6} \mathrm{H}_{4} \mathrm{NH}\right]\left[\mathrm{C}_{5} \mathrm{H}_{9}\left(4-\mathrm{CH}_{3}\right) \mathrm{N}\right]_{2} \mathrm{P}(\mathrm{O})\right\}$ $\mathrm{Sn}\left(\mathrm{CH}_{3}\right)_{2} \mathrm{Cl}_{2}$ (II). To a solution of $\mathrm{SnMe}_{2} \mathrm{Cl}_{2}(0.82 \mathrm{mmol})$ in methanol $(15 \mathrm{ml})$, a methanolic solution of $\left[4-\mathrm{CH}_{3} \mathrm{C}_{6} \mathrm{H}_{4} \mathrm{NH}\right]$ $\mathrm{P}(\mathrm{O})\left[\mathrm{NC}_{5} \mathrm{H}_{9}\left(4-\mathrm{CH}_{3}\right)\right]_{2}$ (1.64 mmol) was added dropwise. The clear solution was stirred under reflux for $48 \mathrm{~h}$. Colourless single crystals were obtained by slow evaporation at room temperature. IR $\left(\mathrm{KBr}, \nu, \mathrm{cm}^{-1}\right)$ : 802, 936, 1070, 1156, 1294, 1370, 1447, 1514, 1614, 2852, 2919, 3253.

\section{Results and discussion}

\section{Crystal structure}

The summary of crystallographic data for (I) and (II) is given in Table 1 and selected bond lengths and angles are listed in Tables 2 and 3.
In the coordination polymer (I), the asymmetric unit (Fig. 1) is composed of the $\mathrm{Sn}\left(\mathrm{CH}_{3}\right)_{2}\left[\mathrm{OP}(\mathrm{O})\left(\mathrm{OCH}_{3}\right)_{2}\right]_{2}$ segment with the $\mathrm{Sn}-\mathrm{C}$ and $\mathrm{Sn}-\mathrm{O}$ bond distances (2.099(3)/2.102(3) $\AA$ and 2.168(2)/2.194(2) $\AA$ ) in good agreement with the published values [33, 38, 39]. Two longer additional $\mathrm{Sn}-\mathrm{O}$ bonds from the oxygen atoms of two adjacent phosphate groups $(2.237(2)$ and 2.241(2) $\AA$ ) connect the molecules into one-dimensional coordination polymer (Fig. 2) extended along the $c$ axis. So, the $\mathrm{Sn}$ atom adopts an $\mathrm{Sn}\left[\mathrm{C}_{2}[\mathrm{O}]_{4}\right.$ coordination environment in the coordination polymer with the trans axial sites occupying by the $\mathrm{C}$-atoms. This aggregation leads to formation of eight-membered $\left[\mathrm{Sn}_{2} \mathrm{P}_{2} \mathrm{O}_{4}\right]$ rings (Scheme 1). Some selected bond angles specifying the distorted octahedron shape at the tin centre and the generated $\left[\mathrm{Sn}_{2} \mathrm{P}_{2} \mathrm{O}_{4}\right]$ rings are as follows: $\mathrm{C} 1-\mathrm{Sn} 1-\mathrm{C} 2$ 175.68(14) ${ }^{\circ}, \mathrm{O} 1-\mathrm{Sn} 1-$ O6 177.51(8) ${ }^{\circ}, \quad$ O1-Sn1-O5 88.76(8) ${ }^{\circ}, \quad$ O2-Sn1-O6 93.65(9) ${ }^{\circ}, \mathrm{Sn}-\mathrm{O}-\mathrm{P} 135.91(13)-161.14(16)^{\circ}$ and P-O-P 117.31(14)-118.32(13) ${ }^{\circ}$. 
Table 2 Selected bond lengths $(\AA)$ and angles $\left({ }^{\circ}\right)$ for complex (I). Symmetry code: (i) $x,-y+1 / 2, z-1 / 2$

\begin{tabular}{lrlr}
\hline Sn1-C1 & $2.102(3)$ & Sn1-O6 & $2.241(2)$ \\
Sn1-C2 & $2.099(3)$ & P1-O1 & $1.490(2)$ \\
Sn1-O1 & $2.168(2)$ & P1-O2 & $1.473(2)$ \\
Sn1-O2 & 2.237(2) & P1-O3 & $1.559(3)$ \\
Sn1-O5 & $2.194(2)$ & P1-O4 & $1.571(2)$ \\
P1-O1-Sn1 & $142.13(14)$ & C1-Sn1-C2 & $175.68(14)$ \\
P1-O2-Sn1 & $161.14(16)$ & C2-Sn1-O1 & $90.62(12)$ \\
P2-O5-Sn1 & $153.51(12)$ & C1-Sn1-O1 & $92.62(12)$ \\
P2-O6-Sn1 & $135.91(13)$ & C2-Sn1-O5 & $92.78(11)$ \\
O2-P1-O1 & $117.31(14)$ & C1-Sn1-O5 & $90.14(11)$ \\
O2-P1-O3 & $112.73(16)$ & O1-Sn1-O5 & $88.76(8)$ \\
O2-P1-O4 & $105.79(14)$ & C2-Sn1-O2 & $88.13(11)$ \\
O1-P1-O3 & $108.07(15)$ & C1-Sn1-O2 & $98.10(11)$ \\
O1-P1-O4 & $110.66(14)$ & O1-Sn1-O2 & $88.67(9)$ \\
O3-P1-O4 & $101.06(16)$ & O5-Sn1-O2 & $177.28(9)$ \\
O6-P2-O5 & $118.32(13)$ & C2-Sn1-O6 & $88.54(12)$ \\
O6-P2-O8 & $111.05(15)$ & C1-Sn1-O6 & $88.33(12)$ \\
O5-P2-O8 & $105.86(12)$ & O1-Sn1-O6 & $177.51(8)$ \\
O6-P2-O7 & $104.58(13)$ & O5-Sn1-O6 & $88.94(8)$ \\
O5-P2-O7 & $109.19(14)$ & O2-Sn1-O6 & $93.65(9)$ \\
O8-P2-O7 & $106.31(13)$ & & \\
\hline
\end{tabular}

In the phosphate ligands $\mathrm{P} 1$ and $\mathrm{P} 2$, the $\mathrm{P}$ atoms are found at the centre of distorted $\mathrm{P}[\mathrm{O}]_{2}[\mathrm{O}]_{2}$ tetrahedron with the $\mathrm{P}-\mathrm{O}$ distances in the range of 1.473(2)-1.490(2) $\AA$ and $1.559(3)-1.573(2) \AA$ for the $\mathrm{P}-\mathrm{O}-\mathrm{Sn}$ and $\mathrm{P}-\mathrm{O}-\mathrm{CH}_{3}$ parts, respectively.

As shown in Fig. 3, the intermolecular C-H...O interactions (labelled $(a)$ for C5-H5b...O7-C8 and labelled (b) for $\mathrm{C} 6-\mathrm{H} 6 \mathrm{~b} . . . \mathrm{O} 2-\mathrm{Sn} 1$ ) exist between the adjacent one-dimensional coordination polymers and form a threedimensional array in the crystal.

The asymmetric unit of (II) (Fig. 4) consists of one complete complex molecule with all atoms located in general positions. So, the $\mathrm{Sn}$ centre is coordinated by two chlorine atoms, two methyl groups and one phosphoric triamide ligand within an $\mathrm{Sn}[\mathrm{C}]_{2}[\mathrm{Cl}]_{2} \mathrm{O}$ coordination environment in a distorted trigonal bipyramidal shape. The phosphoric triamide ligand and one of the chlorine atoms are placed in axial positions with $\mathrm{Cl1}-\mathrm{Sn} 1-\mathrm{O} 1$ bond angle of $177.78(5)^{\circ}$. In the equatorial positions, the bond angles are $\mathrm{Cl} 2-\mathrm{Sn} 1-\mathrm{C} 9105.43(7)^{\circ}, \mathrm{Cl} 2-\mathrm{Sn} 1-\mathrm{C} 24113.99(8)^{\circ}$ and C9-Sn1-C24 140.18(24) ${ }^{\circ}$. The open C9-Sn1-C24 angle is due to the presence of an $\mathrm{Sn}$...Cl interaction from the chlorine atom of the neighbouring complex molecule. A pair of these $\mathrm{Sn}$...Cl interactions (3.8322(6) $\AA$ ) form a dimer (Fig. 5), in opposite to the Sn...O interactions in structure (I) which connect molecules into a coordination polymer.
Table 3 Selected bond lengths $(\AA)$ and angles $\left(^{\circ}\right)$ for complex (II)

\begin{tabular}{lcll}
\hline Sn1-Cl1 & $2.5580(7)$ & P3-O1 & $1.4905(19)$ \\
Sn1-Cl2 & $2.3596(6)$ & P3-N1 & $1.6228(19)$ \\
Sn1-C9 & $2.114(3)$ & P3-N2 & $1.643(2)$ \\
Sn1-C24 & $2.102(3)$ & P3-N3 & $1.631(2)$ \\
Sn1-O1 & $2.211(2)$ & & \\
Cl1-Sn1-Cl2 & $92.69(2)$ & N1-P3-N2 & $108.045(12)$ \\
C11-Sn1-C9 & $93.09(8)$ & N1-P3-N3 & $108.79(9)$ \\
C11-Sn1-C24 & $90.56(9)$ & N2-P3-N3 & $107.57(11)$ \\
C12-Sn1-C9 & $105.43(7)$ & P3-N1-C5 & $118.9(2)$ \\
C12-Sn1-C24 & $113.99(8)$ & P3-N1-C1 & $127.68(18)$ \\
C9-Sn1-C24 & $140.18(24)$ & P3-N2-C7 & $128.16(17)$ \\
O1-P3-N1 & $110.17(11)$ & P3-N3-C15 & $122.55(18)$ \\
O1-P3-N2 & $108.45(12)$ & P3-N3-C19 & $119.35(14)$ \\
O1-P3-N3 & $108.79(9)$ & & \\
\hline
\end{tabular}

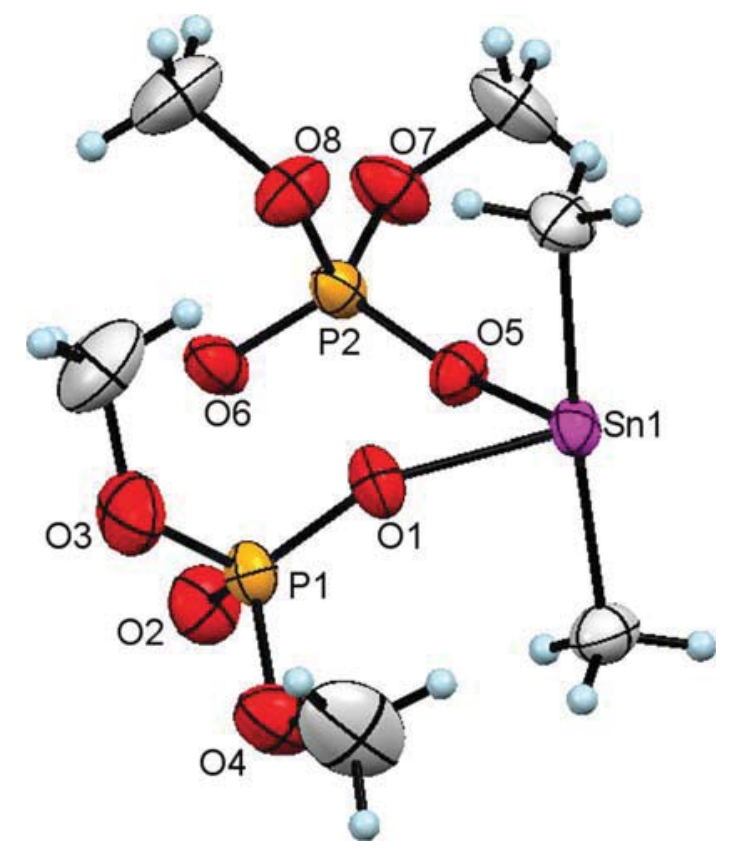

Fig. 1 Asymmetric unit of (I) is shown

As expected from a trigonal bipyramidal geometry, the axial bond length of Sn1-Cl1 (2.5580(7) $\AA$ ) is longer than the equatorial Sn1-Cl2 bond length (2.3596(6) $\AA$ ). This is in agreement with the deposited analogous structure found in the CSD $\mathrm{C}_{20} \mathrm{H}_{50} \mathrm{Cl}_{6} \mathrm{~N}_{6} \mathrm{O}_{4} \mathrm{P}_{2} \mathrm{Sn}_{2}$ (PAGVUQ) [38], where the five-coordinated tin atom has $\mathrm{Sn}-\mathrm{Cl}_{\text {axial }}$ of 2.414(1) $\AA$ and $\mathrm{Sn}-\mathrm{Cl}_{\text {equatorial }}$ of $2.385(1) \AA$. Moreover, in recently published structure by Pourayoubi et al. (2014), similar result was found: $\mathrm{Sn}-\mathrm{Cl}_{\text {axial }}$ of 2.5154(7) $\AA$ and $\mathrm{Sn}-\mathrm{Cl}_{\text {equatorial }}$ of 2.3497 (7) $\AA$.

The phosphoric triamide ligand is coordinated to the tin centre through the oxygen atom of $\mathrm{P}=\mathrm{O}$ group. The tetrahedral configuration at the $\mathrm{P}$ atom is significantly distorted 
Fig. 2 A view of one-dimensional coordination polymer of (I). Colour keys for the atoms: $S n$ purple, $P$ orange, $O$ red, $C$ light grey, $H$ light blue
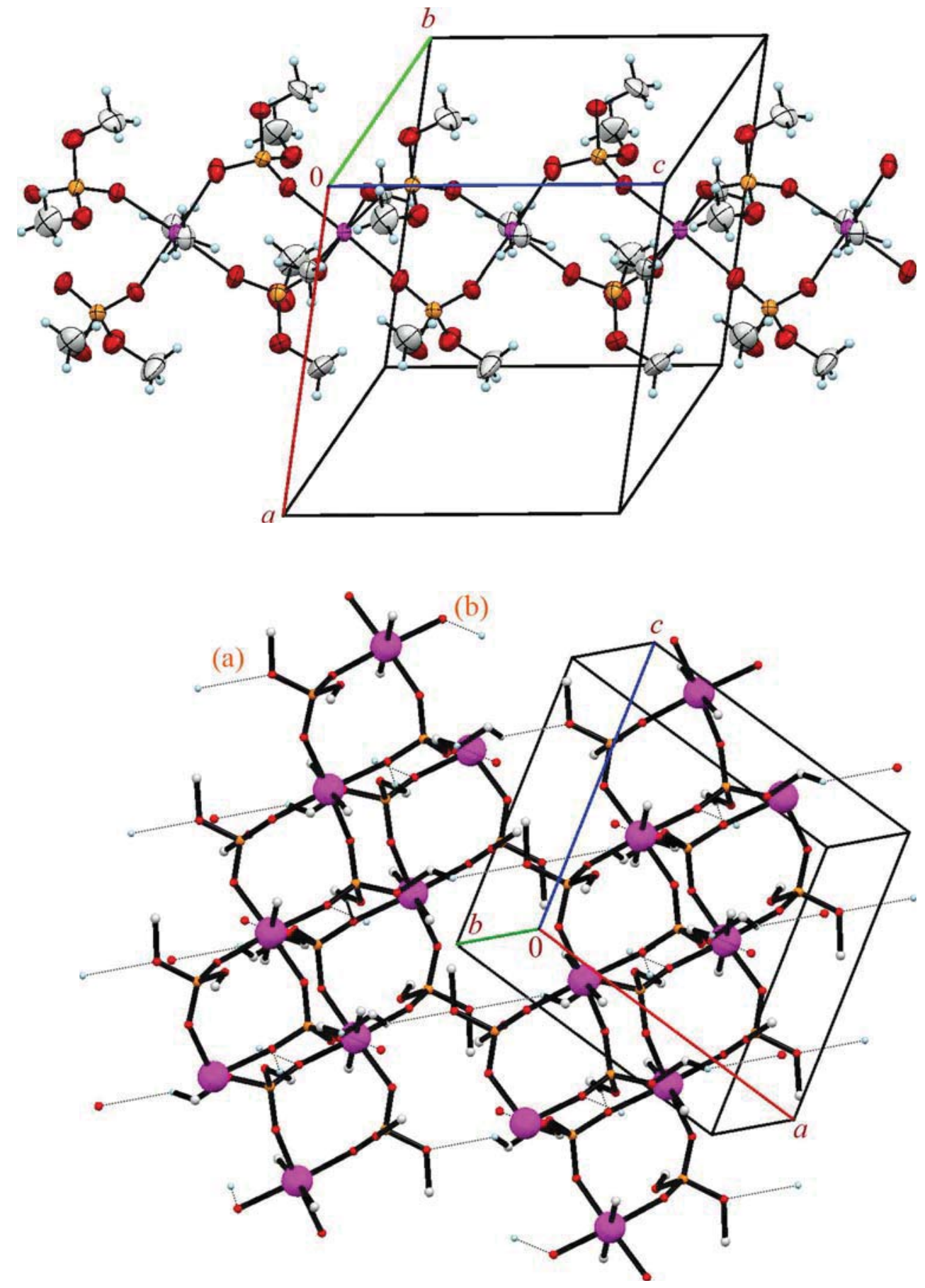

Fig. 3 A view of threedimensional array of (I) built from $\mathrm{C}-\mathrm{H}$... O hydrogen bonds (marked $(a)$ and $(b)$ ) between adjacent one-dimensional coordination polymers. The $\mathrm{H}$ atoms not involved in hydrogen bonding have been omitted for the sake of clarity and the Sn atoms are shown as big purple balls. Colour keys for the other atoms are as the same as in Fig. 2 with the angles in the range $107.57(11)^{\circ}-110.17(11)^{\circ}$. The bond-angle sums at the nitrogen atoms, about $360^{\circ}$ (N1), $359^{\circ}(\mathrm{N} 2)$ and $355^{\circ}(\mathrm{N} 3)$ indicate nearly planar configuration for two nitrogen atoms. The nitrogen atoms do not take part in hydrogen bonding as an acceptor reflecting their low Lewis base character.

In the structure (II), the intermolecular N2-H1n2...Cl1 hydrogen bonds connect molecules in a 1D arrangement along $a$ axis (Fig. 6), where the chlorine atom is the one located at the axial position of $\mathrm{Sn}$.

\section{Hirshfeld surface analysis}

The Hirshfeld surface [39] of a molecule in a crystal is constructed by partitioning space in the crystal into regions where the electron distribution of a sum of spherical atoms 
Fig. 4 Molecular structure and atom labelling scheme for compound (II) with displacement ellipsoids at the $50 \%$ probability level
Fig. 5 Part of crystal structure of (II) showing the $\mathrm{Sn} . . . \mathrm{Cl}$ interactions (dotted lines). The $\mathrm{H}$ atoms have been omitted for clarity
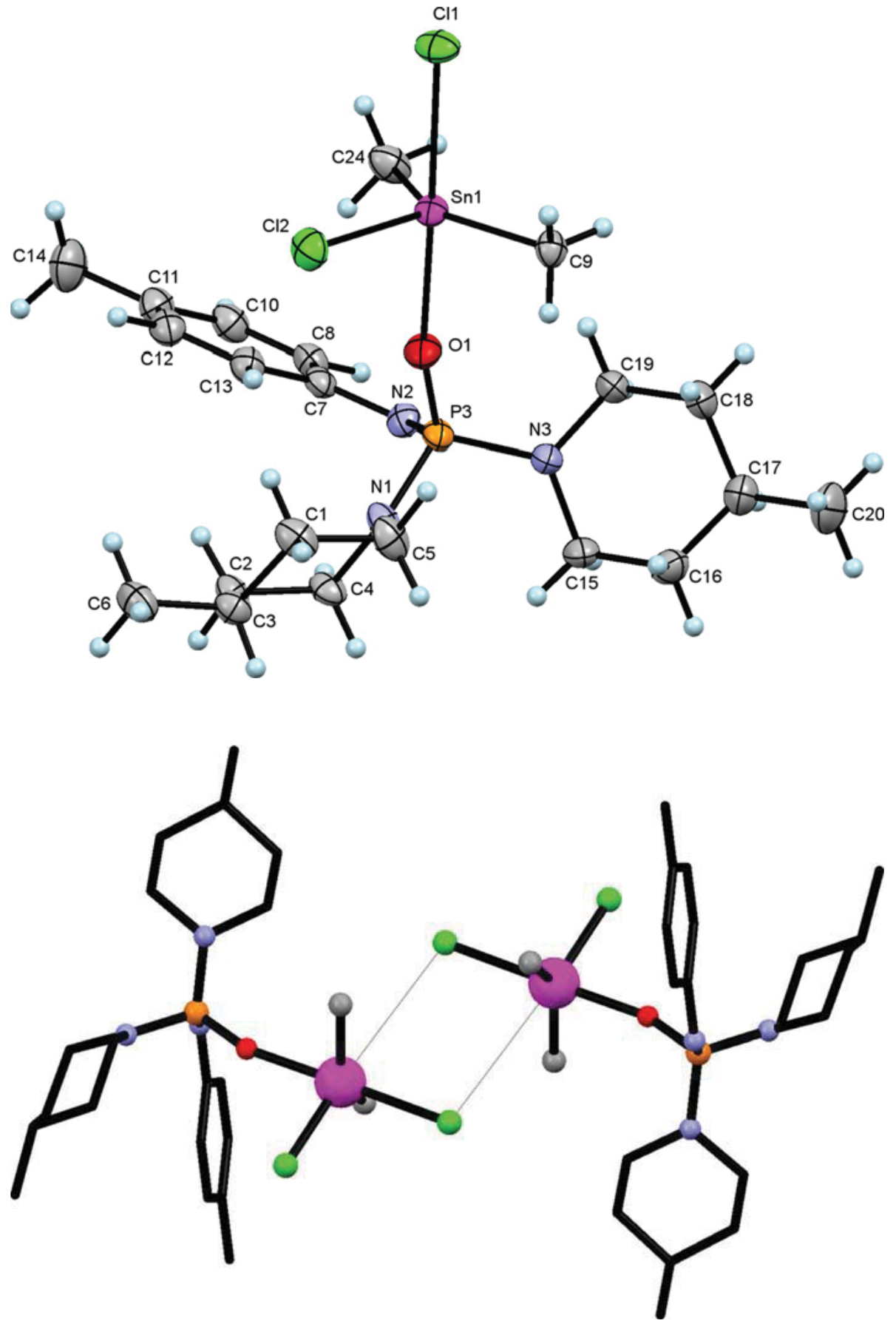

for the molecule (promolecule) dominates the corresponding sum over the crystal (procrystal).

For each point on the Hirshfeld surface, the parameters $d_{\mathrm{e}}$ and $d_{\mathrm{i}}$ describe the distances from a point on the surface to the nearest nucleus outside and inside the surface, respectively [40]. The $d_{\text {norm }}$ value is the sum of the normalised quantities of $d_{\mathrm{i}}$ and $d_{\mathrm{e}}$ by considering the van der Waals radius of atoms involved. This value graphically highlights the regions of the surface involved in a specific type of intermolecular contact by a coloured scheme: red for intermolecular contacts with distances closer than the sum of van der Waals radii; blue and white for contacts, respectively, longer than and equal to the sum of van der Waals radii [41].

The 2D fingerprint of the Hirshfeld surface represents a method for indicating types of intermolecular interactions and also the relative area of the surface corresponding to each kind of interaction. This method provides a 'fingerprint' of the intermolecular interactions in the crystal and a visual summary of the frequency of each combination of $d_{\mathrm{e}}$ 


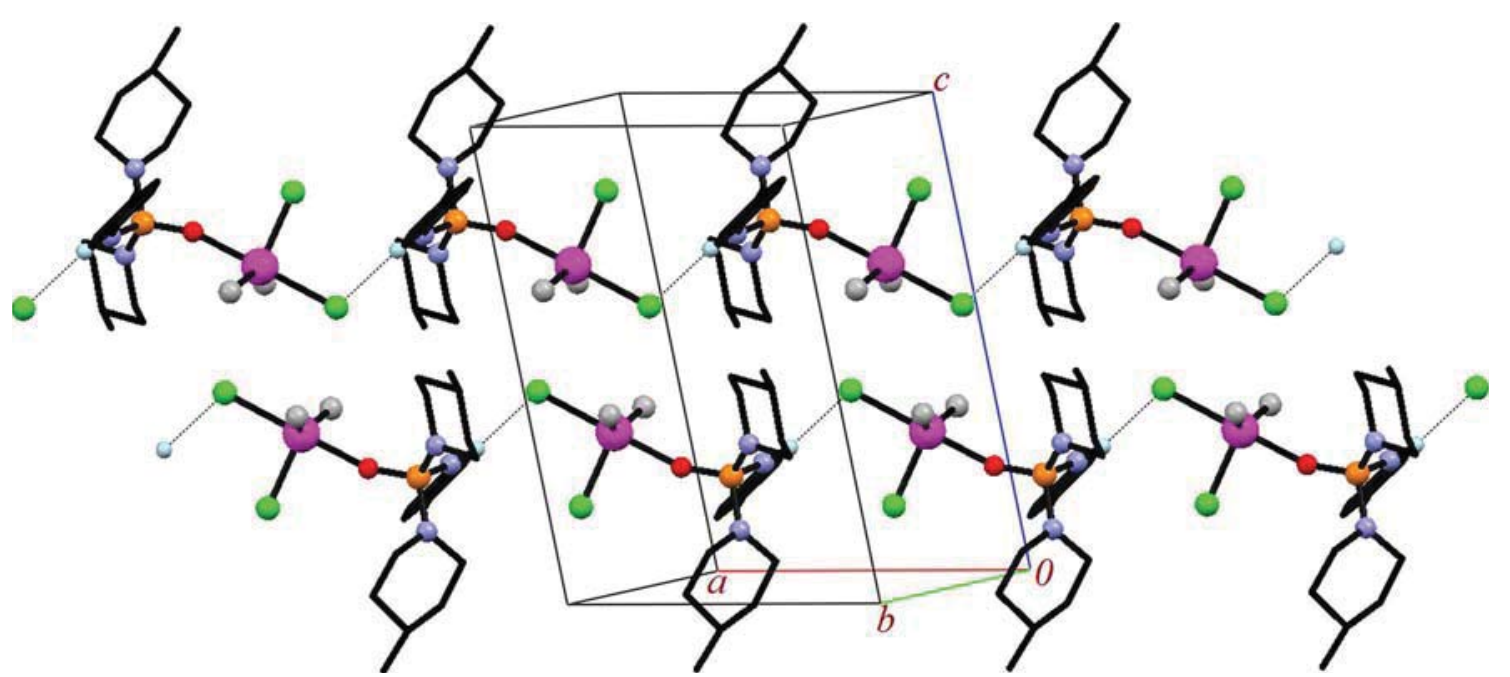

Fig. 6 A view of part of crystal structure of (II) in which intermolecular N-H...Cl hydrogen bond produced the one-dimensional polymeric chain. Only $\mathrm{H}$ atoms involved in hydrogen bonds are shown

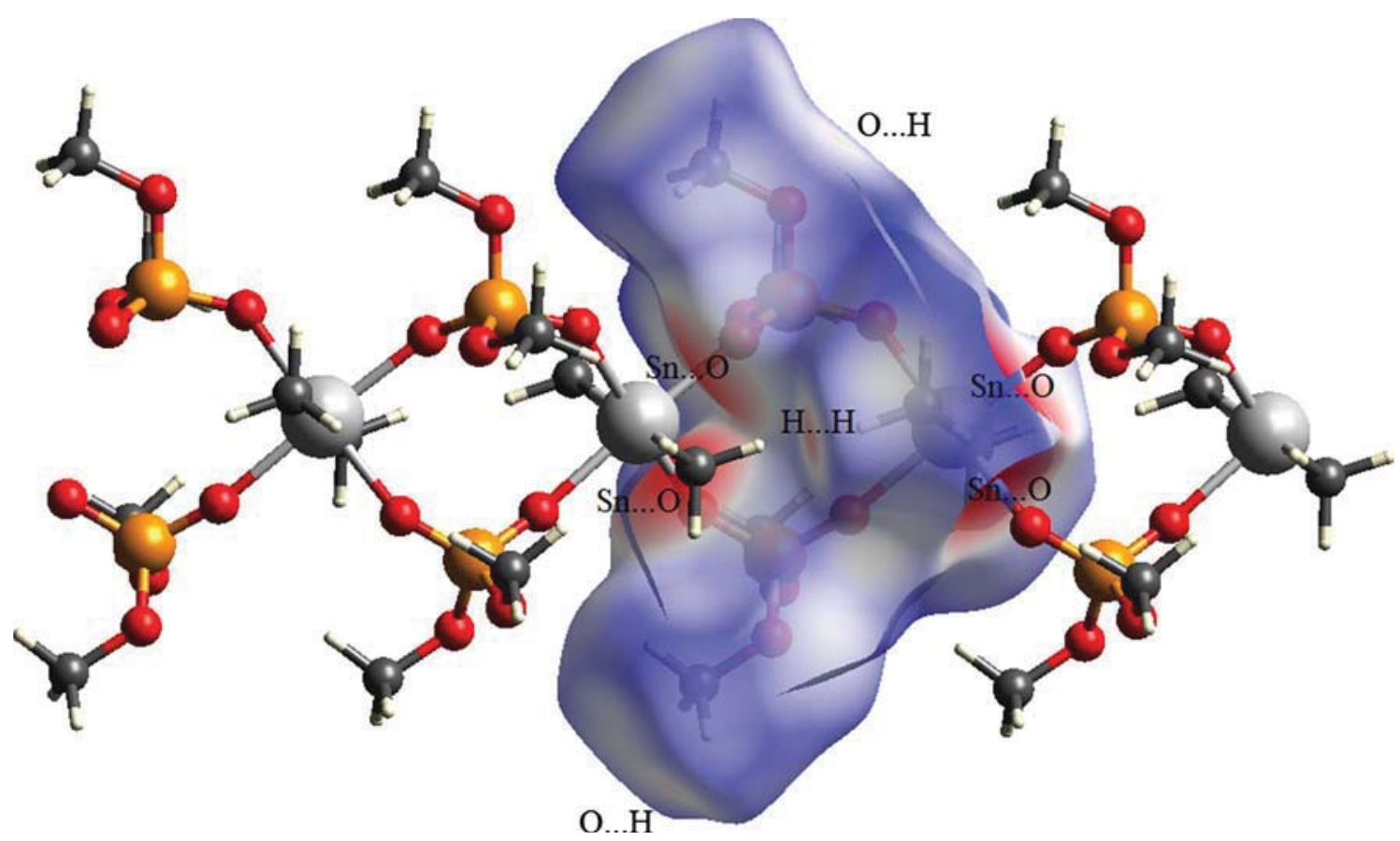

Fig. $7 d_{\text {norm }}$ mapped on Hirshfeld surface for visualizing the intermolecular contacts of the complex (I)

and $d_{\mathrm{i}}$ across the surface of a molecule. Each point on the 2D fingerprint plot corresponds to a unique $\left(d_{\mathrm{e}}, d_{\mathrm{i}}\right)$ pair, and the colour of each point corresponds to the relative area of the surface with that $\left(d_{\mathrm{e}}, d_{\mathrm{i}}\right)$ pair. Points on the plot with no contribution on the surface are left uncoloured, and points with a contribution to the surface are coloured [42].

The Hirshfeld surfaces, mapped with $d_{\text {norm }}$, and 2D fingerprint plots of complexes (I) and (II) were generated using Crystal Explorer 3.1 [43], Figs. 7, 8, 9, 10.
As it is observed in Fig. 7 for complex (I), on the surface mapped, two large hollow red regions on the right side of the figure are related to the Sn...O close contacts. Such contacts between the Sn centre within the Hirshfeld surface and the oxygen atoms of phosphate outside of this surface are responsible for the polymeric structure of (I). On the other hand, two large red bumps on the left of the figure are related to $\mathrm{Sn}$...O contacts, with the oxygen atoms within the surface and Sn outside the surface. 

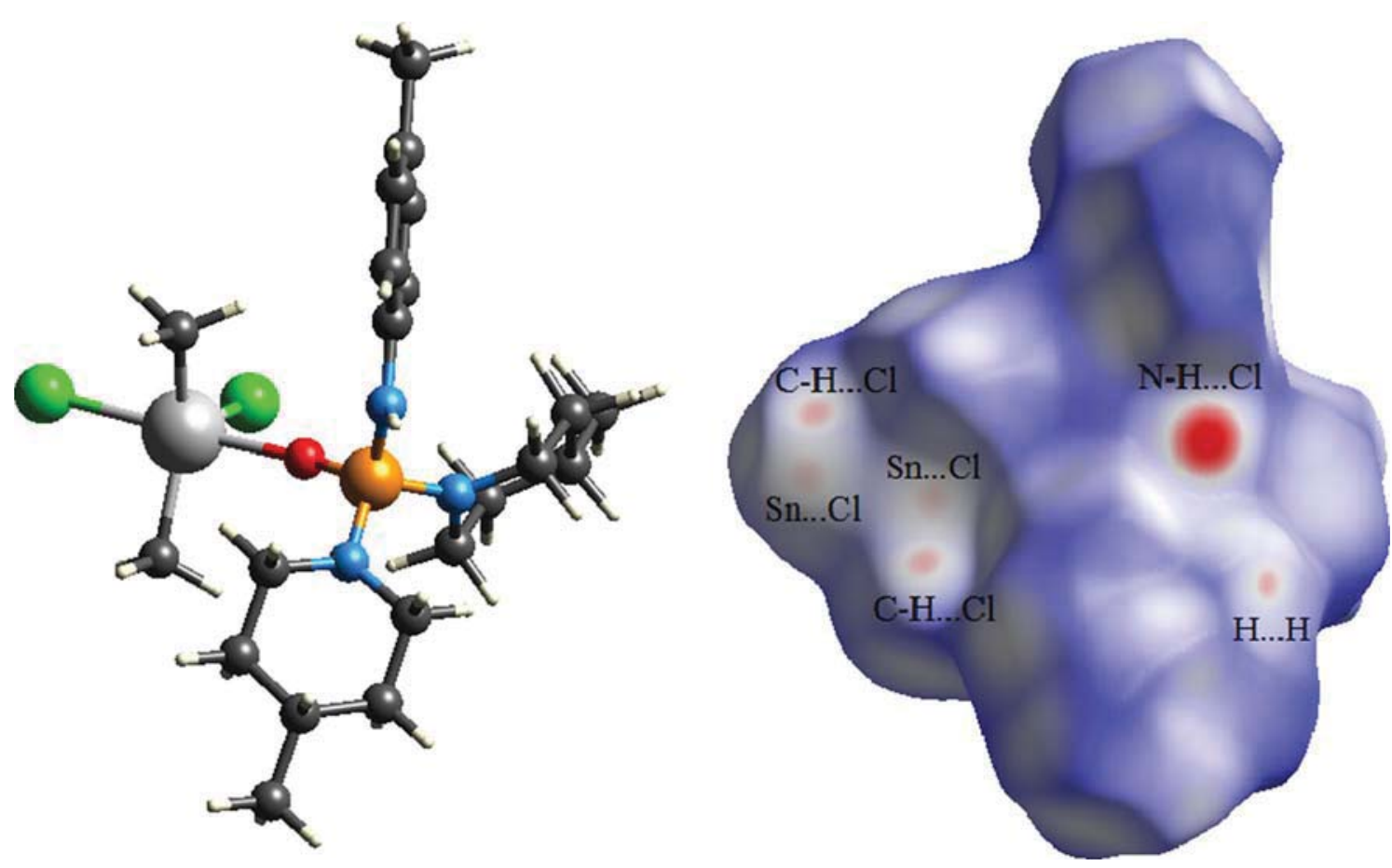

Fig. $8 d_{\text {norm }}$ mapped on Hirshfeld surface for visualizing the intermolecular contacts of the complex (II). The molecule in the left side is in a similar orientation with respect to the Hirshfeld surface

In addition to the noted interactions, the pale red spot, related to $\mathrm{H}$...H contacts, and smaller light red areas, related to two types of $\mathrm{O} \ldots \mathrm{H}$ interactions, are shown in Fig. 7. The $\mathrm{H}$...H contacts are related to the interactions between the $\mathrm{H}$ atoms of two adjacent $\mathrm{Sn}-\mathrm{CH}_{3}$ parts while the $\mathrm{O} \ldots \mathrm{H}$ contacts are the ones discussed in the section related to crystal structure and Fig. 3.

In complex (II), the secondary $\mathrm{Sn} . . . \mathrm{Cl}$ interactions (noted in the previous section) are shown in the Hirshfeld surface as two light red spots. Moreover, the $\mathrm{N}-\mathrm{H}$... $\mathrm{Cl}$ interactions discussed can be seen as the deep red spot (Fig. 8). The other light red spots appeared in this figure are related to the $\mathrm{C}-\mathrm{H} \ldots \mathrm{Cl}$ and $\mathrm{H}$...H interactions.

\section{Fingerprint plots}

Figures 9 and 10 illustrate two-dimensional fingerprint plots (FPs) of the Hirshfeld surfaces for structures (I) and (II), respectively. The Figs. 9a-c and 10a-c indicate division contributions of different interactions which overlap in the full fingerprint plots (Figs. 9d, 10d).

The FPs in Figs. 9a and 10a depict H...H contacts as one distinct spike in each figure with a shortest contact near $1.8 \AA$ for (I) and $2.3 \AA$ for (II) (i.e., the minimum value of $d_{\mathrm{e}}+d_{\mathrm{i}}$ which is less than sum of van der Waals radii for hydrogen atoms [44]). It should be noted that for both structures, the H...H contacts represent the largest relative contribution of $59.1 \%$ for (I) and $73.9 \%$ for (II). The characteristic intermolecular contacts in (I) and (II) are O...H (34.1\%) and $\mathrm{H} . . \mathrm{Cl}(20.2 \%)$, respectively.

Figure $9 \mathrm{~b}$ exhibits two pairs of $\mathrm{H}$-bond spikes for two different $\mathrm{C}-\mathrm{H} . . . \mathrm{O}$ hydrogen bonds in (I). The longer spike corresponds to the $\mathrm{C}-\mathrm{H}$... O hydrogen bond with H...O near $2.6 \AA$, while the shorter spike corresponds to slightly longer distance of $\mathrm{C}-\mathrm{H}$...O hydrogen bond (near $2.7 \AA$ ). In (II), no the H...O interaction exists; instead, we can see in Fig. 10b the points related to the $\mathrm{N}-\mathrm{H}$...Cl and $\mathrm{C}-\mathrm{H}$... Cl contacts. However, both spikes in this Figure are related to the $\mathrm{N}-\mathrm{H} \ldots \mathrm{Cl}$ hydrogen bond with the $d_{\mathrm{e}}+d_{\mathrm{i}} \approx 2.4 \AA$.

The $\mathrm{Sn} . . . \mathrm{O}$ close contacts in (I) are viewed as two sharp spikes in Fig. 9c; whereas, the $\mathrm{Sn} . . . \mathrm{Cl}$ interactions in (II) represent only negligible portion of the total interactions. Furthermore, the structure (I) does not show the C...H interaction; whereas, (II) with unsaturated carbon atoms manifests $5.7 \%$ of such interaction as two very short spikes in Fig. 10c. Finally, the full FPs of each structure are given in Figs. 9d and 10d.

The relative contributions of various intermolecular contacts are summarized in Table 4. From this analysis, the decisive role of weak interactions such as $\mathrm{H} . . . \mathrm{H}$, 


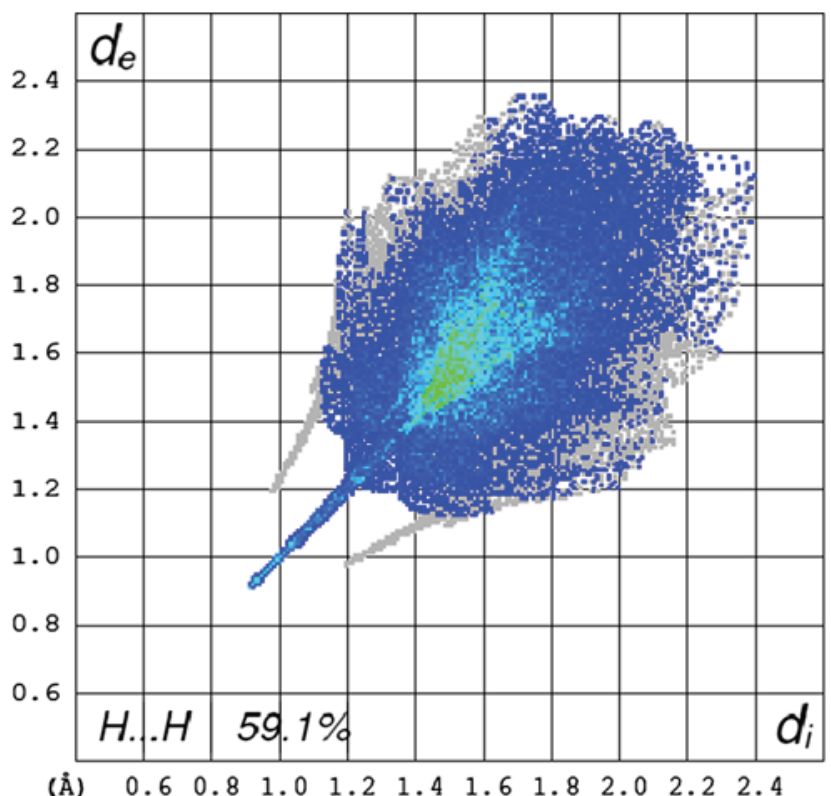

(a)

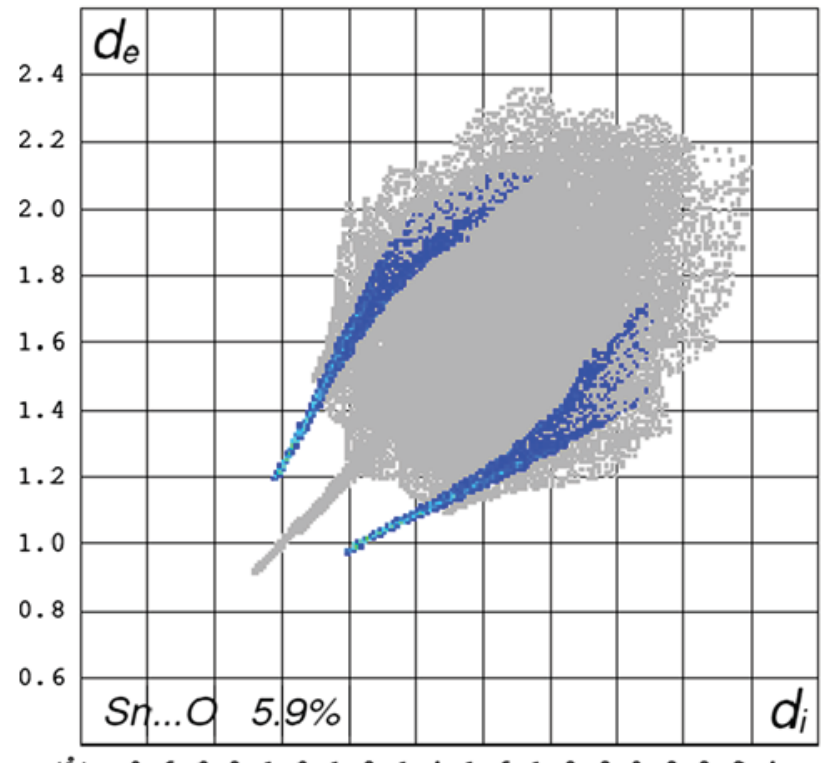

(A) $\quad \begin{array}{llllllllllllll}0.6 & 0.8 & 1.0 & 1.2 & 1.4 & 1.6 & 1.8 & 2.0 & 2.2 & 2.4\end{array}$

(c)

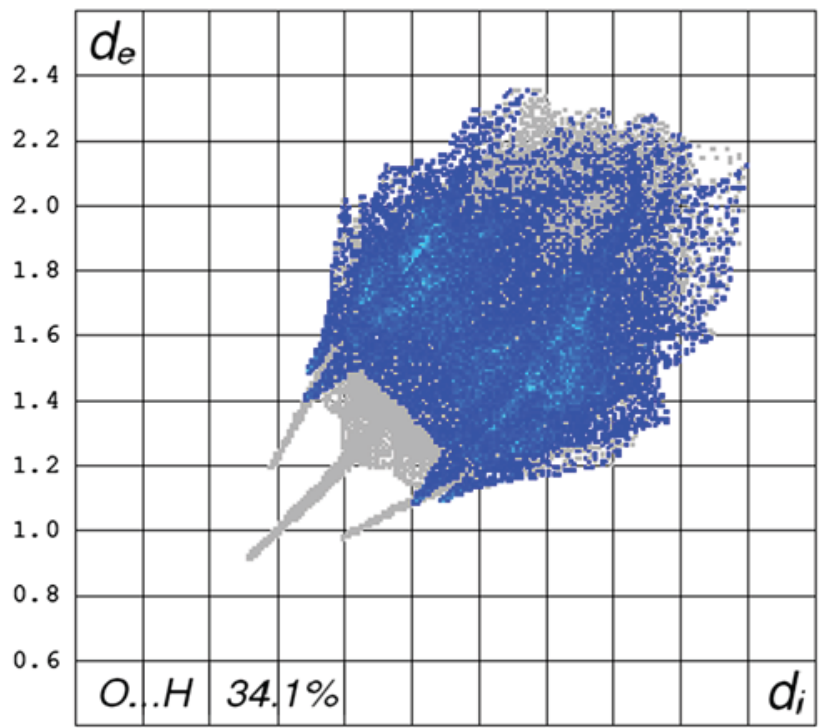

(Á) $\begin{array}{llllllllllllllll}0.6 & 0.8 & 1.0 & 1.2 & 1.4 & 1.6 & 1.8 & 2.0 & 2.2 & 2.4\end{array}$

(b)

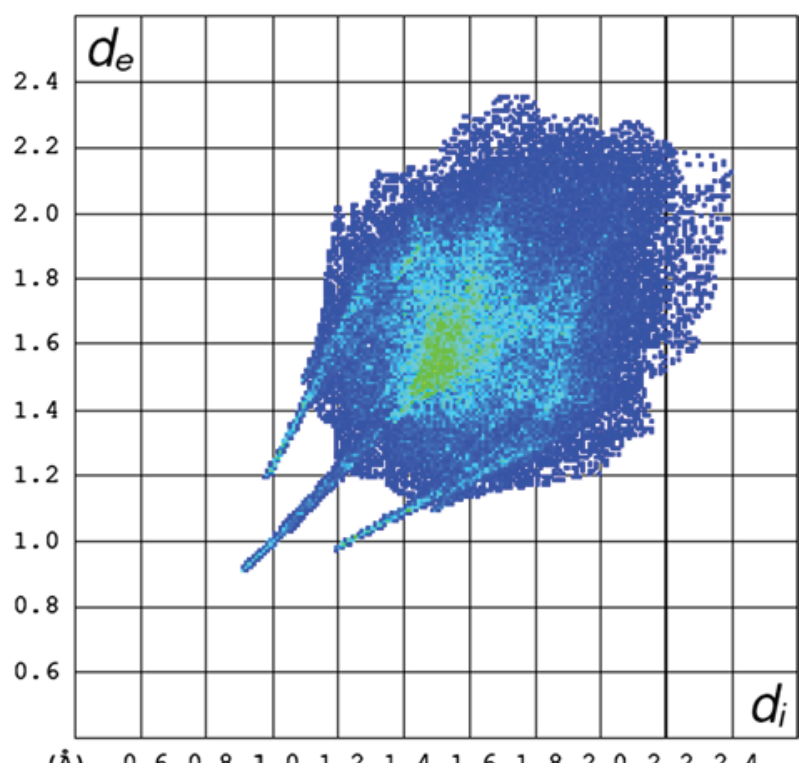

(A) $\quad \begin{array}{llllllllllllll}0.6 & 0.8 & 1.0 & 1.2 & 1.4 & 1.6 & 1.8 & 2.0 & 2.2 & 2.4\end{array}$

(d)

Fig. 9 2D fingerprint plots of the complex (I): a H...H, b O...H, c Sn...O and $\mathbf{d}$ full. The parameter $d_{\mathrm{i}}$ is the closest internal distance from a given point on the Hirshfeld surface while $d_{\mathrm{e}}$ is the closest external contact

$\mathrm{C}-\mathrm{H} \ldots \mathrm{O}$ and $\mathrm{H} \ldots \mathrm{Cl}$ for crystal packing is clearly indicated, caused by the absence of strong hydrogen bonds in these complexes.

\section{Conclusion}

In this work, two new organotin(IV)-phosphoryl complexes with the formula $\left[\mathrm{Sn}\left(\mathrm{CH}_{3}\right)_{2}\left[\mathrm{OP}(\mathrm{O})\left(\mathrm{OCH}_{3}\right)_{2}\right]_{2}\right]_{\mathrm{n}}$ (I) and
$\left\{\left[\left(4-\mathrm{CH}_{3}\right) \mathrm{C}_{6} \mathrm{H}_{4} \mathrm{NH}\right]\left[\mathrm{C}_{5} \mathrm{H}_{9}\left(4-\mathrm{CH}_{3}\right) \mathrm{N}\right]_{2} \mathrm{P}(\mathrm{O})\right\} \mathrm{Sn}\left(\mathrm{CH}_{3}\right)_{2} \mathrm{Cl}_{2}$ (II) were structurally studied. According to the crystal structure analysis, the geometry around the tin centre is octahedral for the compound (I) $\left(\mathrm{Sn}[\mathrm{C}]_{2}[\mathrm{O}]_{4}\right)$ and trigonal bipyramidal for the compound (II) $\left(\mathrm{Sn}[\mathrm{C}]_{2}[\mathrm{Cl}]_{2} \mathrm{O}\right)$. Moreover, decoding of intermolecular interactions using Hirshfeld surface analysis showed the presence of O...H and Sn...O interactions in (I), $\mathrm{Cl}$...H and C...H interactions in (II) and H...H contacts in both structures. All of these interactions in related Hirshfeld 


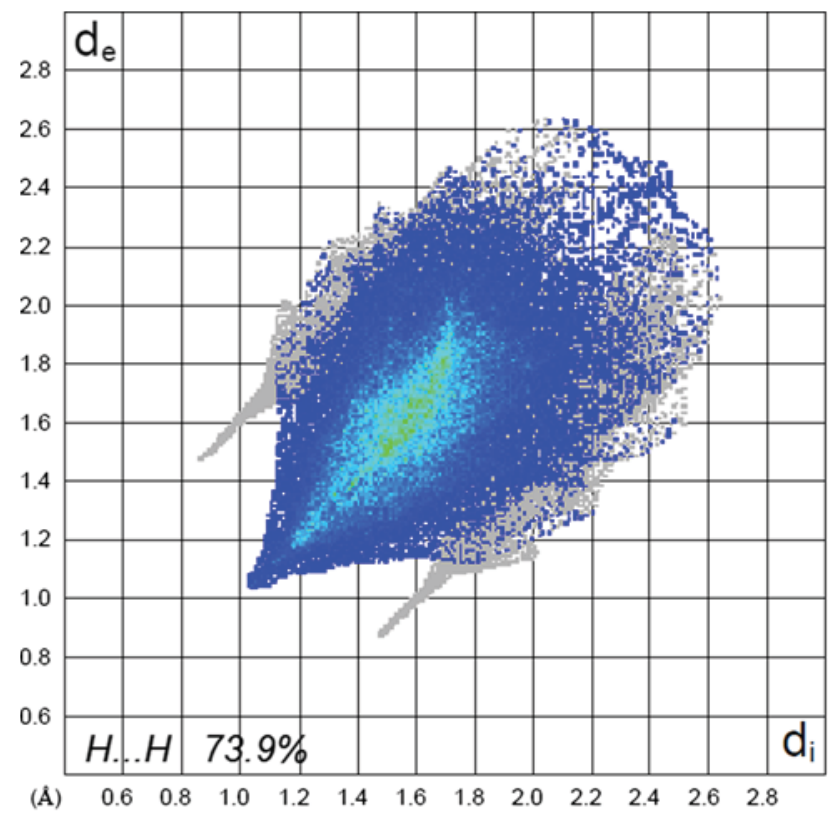

(a)

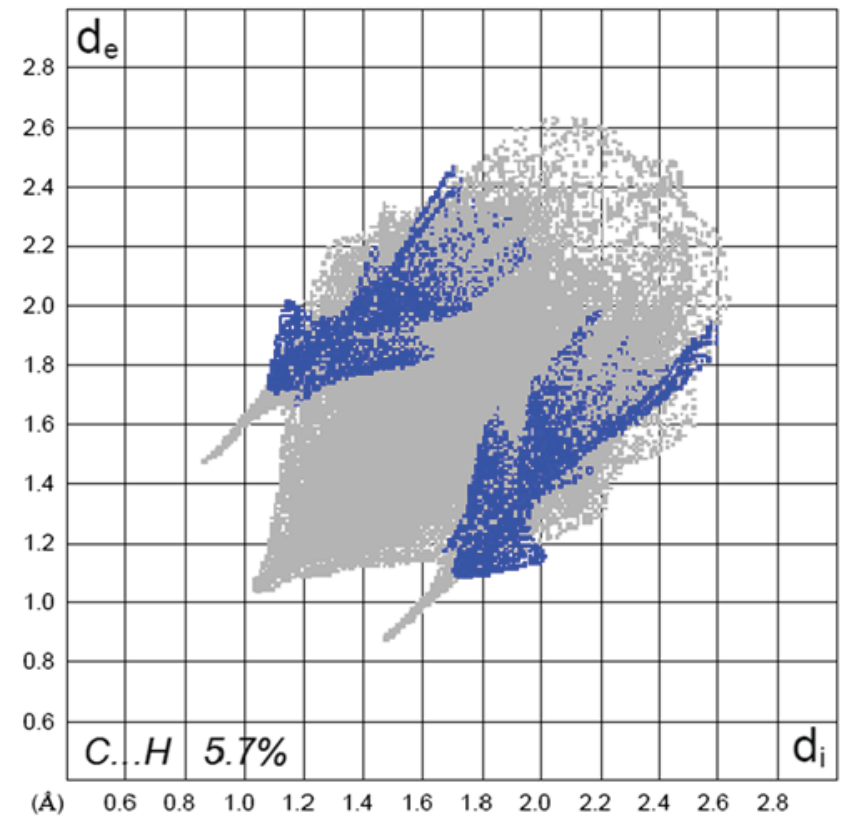

(c)

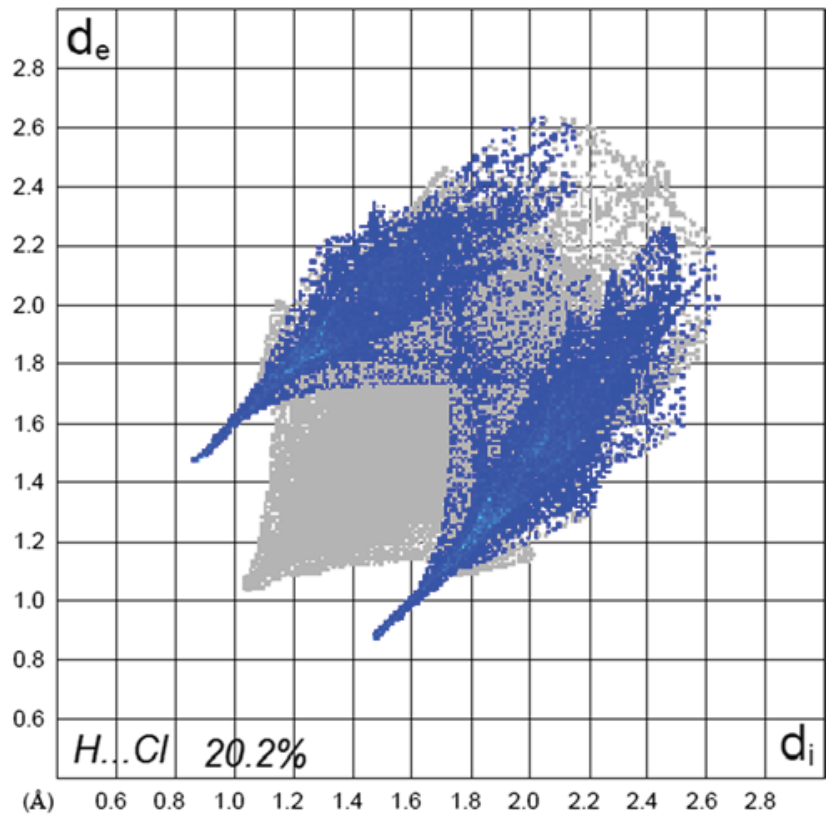

(b)

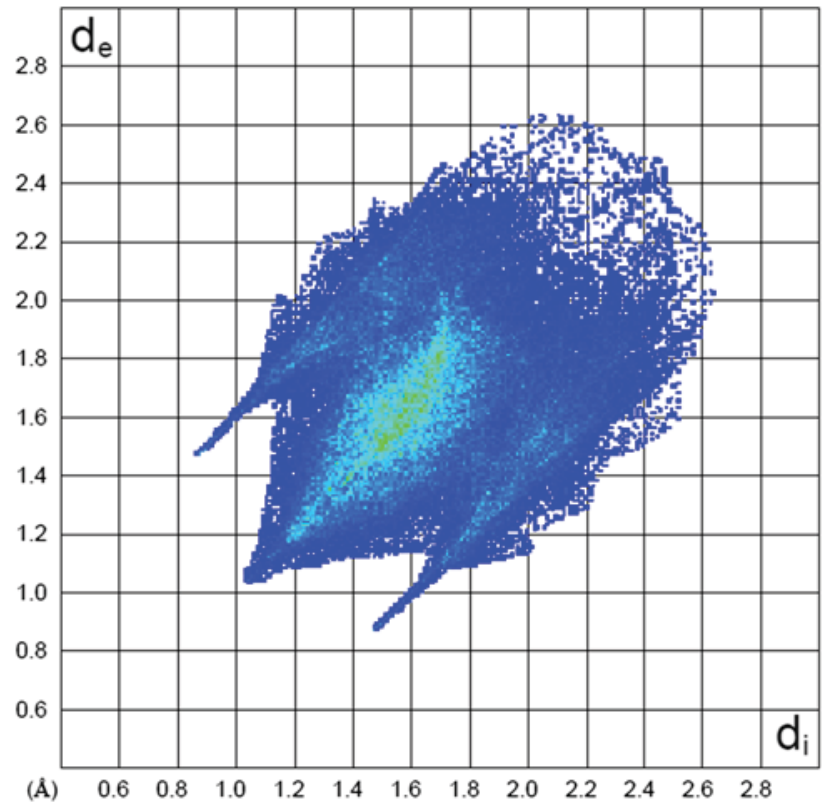

(d)

Fig. 10 2D fingerprint plots of the complex (II): a H...H, b H...Cl, c C...H and d full

Table 4 Summary of the various contacts contributions to the Hirshfeld surface area in (I) and (II)

\begin{tabular}{llllll}
\hline & $\mathrm{H} \ldots \mathrm{H}$ & $\mathrm{O} \ldots \mathrm{H}$ & $\mathrm{Sn} \ldots \mathrm{O}$ & $\mathrm{Cl} \ldots \mathrm{H}$ & $\mathrm{C} \ldots \mathrm{H}$ \\
\hline $\mathrm{I}$ & 59.1 & 34.1 & 5.9 & - & - \\
$\mathrm{II}$ & 73.9 & - & - & 20.2 & 5.7 \\
\hline
\end{tabular}

surface maps appear as red regions and manifest in corresponding 2D fingerprint plots as one spike (for H...H contact) or pair of spikes (for the other interactions).

Acknowledgments Support of this investigation by Ferdowsi University of Mashhad is gratefully acknowledged. Crystallography 
experiments have been supported by the FriMat, the University of Fribourg for structure (I) and by the project 14-03276S of the Czech Science Foundation for structure (II).

\section{Appendix A. Supplementary data}

CCDC numbers of (I) and (II) are 1024228 and 1037302. These data can be obtained free of charge via http://www. ccdc.cam.ac.uk/conts/retrieving.html, or from the Cambridge Crystallographic Data Centre, 12 Union Road, Cambridge CB2 1EZ, UK; fax: (+44) 1223-336-033, or e-mail: deposit@ccdc.cam.ac.uk.

\section{References}

1. L. Niu, Y. Li, Q. Li, Inorg. Chim. Acta 423, 2-13 (2014)

2. C.E. Carraher Jr, M.R. Roner, J. Organomet. Chem. 751, 67-82 (2014)

3. S.K. Hadjikakou, N. Hadjiliadis, Coord. Chem. Rev. 253, 235249 (2009)

4. L. Pellerito, L. Nagy, Coord. Chem. Rev. 224, 111-150 (2002)

5. C. Ma, M. Yang, R. Zhang, J. Li, Inorg. Chem. Commun. 10, 1330-1334 (2007)

6. S. Vassiliou, A. Grabowiecka, P. Kosikowska, A. Yiotakis, P. Kafarski, L. Berlicki, J. Med. Chem. 51, 5736-5744 (2008)

7. Y. Mehellou, C. McGuigan, A. Brancale, J. Balzarini, Bioorg. Med. Chem. Lett. 17, 3666-3669 (2007)

8. R.J. Hansen, S.M. Ludeman, S.J. Paikoff, A.E. Pegg, M.E. Dolan, DNA Repair 6, 1145-1154 (2007)

9. X.J. Zou, G.Y. Jin, Z.X. Zhang, J. Agric. Food Chem. 50, 1451$1454(2002)$

10. R.D. O'Brien, J. Agric. Food Chem. 11, 163-166 (1963)

11. A.J. Metta-Magaña, M. Pourayoubi, K.H. Pannell, M. Rostami Chaijan, H. Eshtiagh-Hosseini, J. Mol. Struct. 1014, 38-46 (2012)

12. M. Pourayoubi, J.A. Golen, M. Rostami Chaijan, V. Divjakovic, M. Negari, A.L. Rheingold, Acta Cryst. Sect. C 67, m160-m164 (2011)

13. R. Kapoor, A. Gupta, P. Venugopalan, A.P. Singh Pannu, M. Singh Hundal, P. Kapoor, J. Organomet. Chem. 694, 623-629 (2009)

14. K. Gholivand, Z. Shariatinia, M. Pourayoubi, Polyhedron 25, 711-721 (2006)

15. K. Gholivand, S. Farshadian, Inorg. Chim. Acta 368, 111-123 (2011)

16. M. Pourayoubi, M. Toghraee, R.J. Butcher, V. Divjakovic, Struct. Chem. 24, 1135-1144 (2013)

17. M.A. Sanhoury, M.T. Ben Dhia, M.R. Khaddar, J. Fluorine Chem. 132, 865-869 (2011)
18. R. Zhang, J. Wu, Q. Wang, C. Ma, Heteroat. Chem. 21, 298-303 (2010)

19. C. Ma, J. Zhang, Q. Jiang, R. Zhang, Inorg. Chim. Acta 357, 2791-2797 (2004)

20. E.G. Zinov'eva, V.A. Efimov, N.I. Kol'tsov, R.Z. Musin, M.N. Dimukhametov, A.T. Gubaidullin, D.B. Krivolapov, Zh. Obshch. Khim. (Russ. J. Gen. Chem.) 78, 1274-1289 (2008)

21. R. Murugavel, S. Shanmugan, Organometallics 27, 2784-2788 (2008)

22. L.F. Piedra-Garza, S. Reinoso, M.H. Dickman, M.M. Sanguineti, U. Kortz, Dalton Trans. 6231-6234 (2009)

23. M.T. Ben Dhia, M.A. Sanhoury, K. Essalah, M.R. Khaddar Phosphorus, Sulfur Silicon Relat. Elem. 186, 1922-1931 (2011)

24. T. Munguia, M. López-Cardoso, F. Cervantes-Lee, K.H. Pannell, Inorg. Chem. 46, 1305-1314 (2007)

25. R. Murugavel, R. Pothiraja, S. Shanmugan, J. Organomet. Chem. 692, 1920-1923 (2007)

26. K. Sakamoto, H. Ikeda, H. Akashi, T. Fukuyama, A. Orita, J. Otera, Organometallics 19, 3242-3248 (2008)

27. P. Ramaswamy, S. Natarajan, Eur. J. Inorg. Chem. 17, $3463-$ 3471 (2006)

28. J.P. Ashmore, T. Chivers, K.A. Kerr, J.H.G. Van Roode, Inorg. Chem. 16, 191-197 (1977)

29. S.W. Ng, Acta Cryst. Sect. C 54, 745-750 (1998)

30. K.C. Molloy, F.A.K. Nasser, C.L. Barnes, D. Van der Helm, J.J. Zuckerman, Inorg. Chem. 21, 960-964 (1982)

31. K.C.K. Swamy, C.G. Schmid, R.O. Day, R.R. Holmes, J. Am. Chem. Soc. 112, 223-228 (1990)

32. F.H. Allen, Acta Cryst. Sect. B 58, 380-388 (2002)

33. M. Pourayoubi, S. Shoghpour Bayraq, A. Tarahhomi, M. Nečas, K. Fejfarová, M. Dušek, J. Organomet. Chem. 751, 508-518 (2014)

34. T. Chivers, M. Krahn, G. Schatte, M. Parvez, Inorg. Chem. 42, 3994-4005 (2003)

35. G.M. Sheldrick, Acta Cryst. Sect. C 71, 3-8 (2015)

36. L. Palatinus, G. Chapuis, J. Appl. Crystallogr. 40, 786-790 (2007)

37. V. Petříček, M. Dušek, L. Palatinus, Z. Kristallogr. 229, 345-352 (2014)

38. K. Gholivand, S. Farshadian, Z. Hosseini, J. Organomet. Chem. 696, 4298-4308 (2012)

39. J.J. McKinnon, M.A. Spackman, A.S. Mitchell, Acta Cryst. Sect. B 60, 627-668 (2004)

40. M.A. Spackman, D. Jayatilaka, CrystEngComm 11, 19-32 (2009)

41. J.J. McKinnon, D. Jayatilaka, M.A. Spackman, Chem. Commun. 3814-3816 (2007)

42. M.A. Spackman, J.J. McKinnon, CrystEngComm 4, 378-392 (2002)

43. S.K. Wolff, D.J. Grimwood, J.J. McKinnon, M.J. Turner, D. Jayatilaka, M.A. Spackman, CrystalExplorer version 3.1, 2013 (University of Western Australia: Perth)

44. G.R. Desiraju, T. Steiner, The Weak Hydrogen Bond (Oxford University Press, Oxford, 1999) 